\title{
The Cricotopus (Oliveiriella) (Diptera: Chironomidae) of the High Altitude Andean Streams, with Description of a New Species, C. (O.) rieradevallae
}

\author{
N Prat ${ }^{1}$ (D, A Paggi ${ }^{2}$, C Ribera ${ }^{3}$, R Acosta $^{1}$, B Ríos-Touma $^{4}$, C Villamarín $^{4}$, F Rivera $^{5}$, P Ossa $^{5}$, \\ M RieRADEVALL ${ }^{1}$
}

${ }^{1}$ Freshwater Ecology and Management Research Group, Dept de Biologia Evolutiva, Ecologia i Ciències Ambientals, Univ de Barcelona, Barcelona, Spain

${ }^{2}$ Instituto de Limnología "Dr. R. A. Ringuelet" (ILPLA, CONICET, UNLP), La Plata, Argentina

${ }^{3}$ Institut de Recerca de la Biodiversitat (IRbio), Dept de Biologia Evolutiva, Ecologia i Ciències Ambientals, Univ de Barcelona, Barcelona, Spain ${ }^{4}$ Unidad de Biotecnología y Medio Ambiente (BIOMA), Facultad de Ingenierías y Ciencias Agropecuarias (FICA), Ingeniería Ambiental, Univ de las Américas, Quito, Ecuador

${ }^{5}$ Research Group GEBIOME, Depto de Ciencias Biológicas, Facultad de Ciencias Exactas y Naturales, Univ de Caldas, Manizales, Colombia

\section{Keywords}

Biogeography, taxonomy, Cox1 mitochondrial sequences, Midges, Orthocladiinae, South America

\section{Correspondence}

Depto de Biologia Evolutiva, Ecologia i Medi Ambient. Universitat de Barcelona. Diagonal, 643. 08028 Barcelona, Spain

M Rieradevall is deceased

Edited by Ranyse Barbosa Querino

Received 9 November 2016 and accepted 18 July 2017

Published online: 13 September 2017

(C) Sociedade Entomológica do Brasil 2017

\begin{abstract}
The genus Oliveiriella (Chironomidae, Orthocladiinae) was erected by Wiedenbrug \& Fittkau (1997). The adults have characteristic black spots on their wings and other characteristics similar to the genus Cricotopus. Pupal skins are very characteristic with strong short spines in the anal lobe instead of setae, while larvae are distinguishable by the long anal papillae and the intense blue color of their body. However, Andersen et al (2013) consider Oliveiriella as a subgenera of Cricotopus. In this paper, using the sequences of the cox1 gene, we conclude that Oliveiriella should be considered a subgenus within Cricotopus, confirming its status in Andersen et al (2013). Furthermore, we describe Cricotopus (Oliveiriella) rieradevallae Prat \& Paggi sp. n. from the Saltana river (Ecuador). The adult males, females, and preimaginal stages of the two species of subgenus Oliveiriella known from South America Cricotopus (O.) almeidai n. comb. from Peru, Brazil, and Argentina and Cricotopus (O.) sanjavieri n. comb. from Argentina are compared with those of Cricotopus $(O$.) rieradevallae sp. n. from Ecuador. The differences allow the distinction of the three species. The cox1 gene reveals that at least three different undescribed species of the same subgenus are present in the high-altitude tropical Andes. The morphology of the available pupae and pupal exuviae reveals the presence of several morphotypes that are candidates to be described as new species. A key used to distinguish these pupal morphotypes is provided, including the three described species. Additionally, the distribution of the subgenus is discussed.
\end{abstract}

\section{Introduction}

The genus Oliveiriella was erected by Wiedenbrug \& Fittkau (1997) from material studied from Rio Grande do Sul (southern Brazil) by Oliveira (1946), described originally as
Spaniotoma (Stictocladius) almeidai. Years later, Tejerina \& Paggi (2009) described a new species from Argentina, Oliveiriella sanjavieri, in all stages. In the same year, the range of Oliveiriella was extended to North America by Krestian et al (2009), which found larvae and pupae of this 
species in Arizona and New Mexico. Today, due to morphological similarities with Cricotopus, Oliveiriella is considered a synonym of Cricotopus but is maintained as a separate subgenus according to Andersen et al (2013). Therefore, in this paper, we will use Oliveiriella as a subgenus of Cricotopus. Andersen et al (2013) provided a key to distinguish between the different Cricotopus subgenera larvae. Prat et al (2014) provided a key for the pupae of the high-altitude Andean Chironomidae genus where Oliveiriella can be easily distinguished from other genera and subgenera of Orthocladiinae.

Larvae of Oliveiriella have been found in lotic habitats of montane and submontane streams from southern to southeastern Brazil, and on the eastern slopes of the Andes in Ecuador and Peru by Wiedenbrug \& Fittkau (1997), but the authors do not provide the altitude at which the larvae were found. Oliveiriella sanjavieri was found by Tejerina \& Paggi (2009) and Tejerina \& Malizia (2012) from several streams in the region of Tucumán (Argentina) in altitudes ranging from 825 to $1275 \mathrm{~m}$ a.s.l. and in two streams located at 411 and $505 \mathrm{~m}$ a.s.l. in the region of Jujuy (Argentina). Finally, pupae of Oliveiriella were collected by Krestian et al (2009) in Arizona and New Mexico, from two rivers at elevations between 1180 and $1449 \mathrm{~m}$ a.s.l. In all cases, streams where the larvae have been found until now are of clear and oligotrophic waters. During our studies in the high-altitude tropical streams in Colombia, Ecuador, and Peru, we found larvae, pupae, and pupal exuviae of Cricotopus (Oliveiriella) in Peru, Ecuador, and Colombia. In this paper, we used all this material to (1) present a phylogenetic tree of the Oliveiriella species using $\mathrm{COI}$ sequences that support that Oliveiriella is a subgenus of Cricotopus; (2) describe a new species of this subgenus found in Saltana creek (Pichincha, Ecuador); (3) report the distribution of the subgenus in the high-altitude Andean rivers; (4) study the morphological variation of larvae and pupae of this subgenus; and (5) provide a preliminary key of the different morphotypes of pupal exuviae.

\section{Material and Methods}

\section{Study area}

Samples were taken in the tropical highland Andean streams (over $2500 \mathrm{~m}$ a.s.l) from northern Colombia to southern Peru. A total of 185 sites were studied in four different research projects from 2007 to 2011 (Table 1). From all the sites sampled, the subgenus Oliveiriella was found only in eight sites. The sites with Oliveiriella, the date, country, basin, stream, position, and altitude are listed in Table 1. In this table, we also indicate the research project in which the site was studied. Details of the projects and sites may be found at http://www.ub.edu/ riosandes/. Each site was visited once, except site GUAY o4 from the FUCARA project when samples were taken from April 2009 to November 2010. Physicochemical, habitat (IHF index), and riparian vegetation (QBR index) characteristics of the sampled sites are listed in Table 2. Material collected from one site in Colombia (VR-6; Table 1) by two of the authors (FR, $\mathrm{PO})$ has been included in the molecular studies. The two species currently known, Cricotopus (O.) almeidai and Cricotopus (O.) sanjavieri, have also been used for comparison with the description of Cricotopus (O.) rieradevallae sp. n. Larvae and pupae of $C$. (O.) almeidai were collected from Los Sosa river, Tucumán, Argentina. We were unable to amplify the DNA of the larvae of $C$. (O.) sanjavieri sampled at San Javier stream, Tucumán, Argentina. For this reason, it was not possible to include this species in the phylogenetic tree.

\section{Sampling, sorting, and preservation of material}

Sampling of larvae and pupae or pupal exuviae was done using a Surber sampler in the CERA and BIQURA projects (Villamarín et al 2013, Prat et al 2013) and a Hess sampler at Saltana creek in the FUCARA project (Ríos-Touma et al 2011). Surber samples were taken in different substrates following the protocol described by Villamarín et al (2013). To enhance the collection of pupae and pupal exuviae, drift samples were also taken. At least two drift nets were left in the river to filter the water in each site during the time used for sampling of benthos with the Surber sampler (2$3 \mathrm{~h}$ ). In all cases, the net mesh was $250 \mu \mathrm{m}$. In the case of the site GUAYO4 (Saltana creek, FUCARA project), Hess samples were taken randomly, every month from April 2009 to August 2010 using the methods reported in Ríos-Touma et al (2012).

Except in the BIQURA project, samples were fixed with formalin in the field, taken to the laboratory, where, after elimination of formalin from the sample, Chironomidae were sorted. At least 100 individuals per sample were collected. In all cases, chironomid larvae were identified at genera or morphotype level under the stereoscope following the key of Prat et al (2012). Up to 10 individuals of each genera or morphotype were prepared for microscope examination. The larvae were digested in hot $10 \% \mathrm{KOH}$, washed, dehydrated, and mounted in Euparal ${ }^{\circledR}$ on a slide following the usual techniques for optical microscopy described by Epler (2001).

In the BIQURA project, the main objective was to obtain the barcode of the maximum taxa possible. Live larvae were collected in the field (at least 100 individuals) picking the organisms from a combined sample of 12 Surbers including all the inhabitants found in the stream. The midges were then fixed in the field using $96 \%$ alcohol that was changed at least once before the DNA analyses were carried out. The body of the larvae was used for DNA extraction, while the head capsule was prepared following the methods previously described. The pupae (or pupal exuviae) were prepared after the DNA extraction (described further on in the text) in Euparal ${ }^{\circledR}$ using the same protocol of larvae. All the larvae were classified using the key of Prat et al (2012) and other papers referred to by the authors. For pupae, the key of Prat et al (2014) was used. 

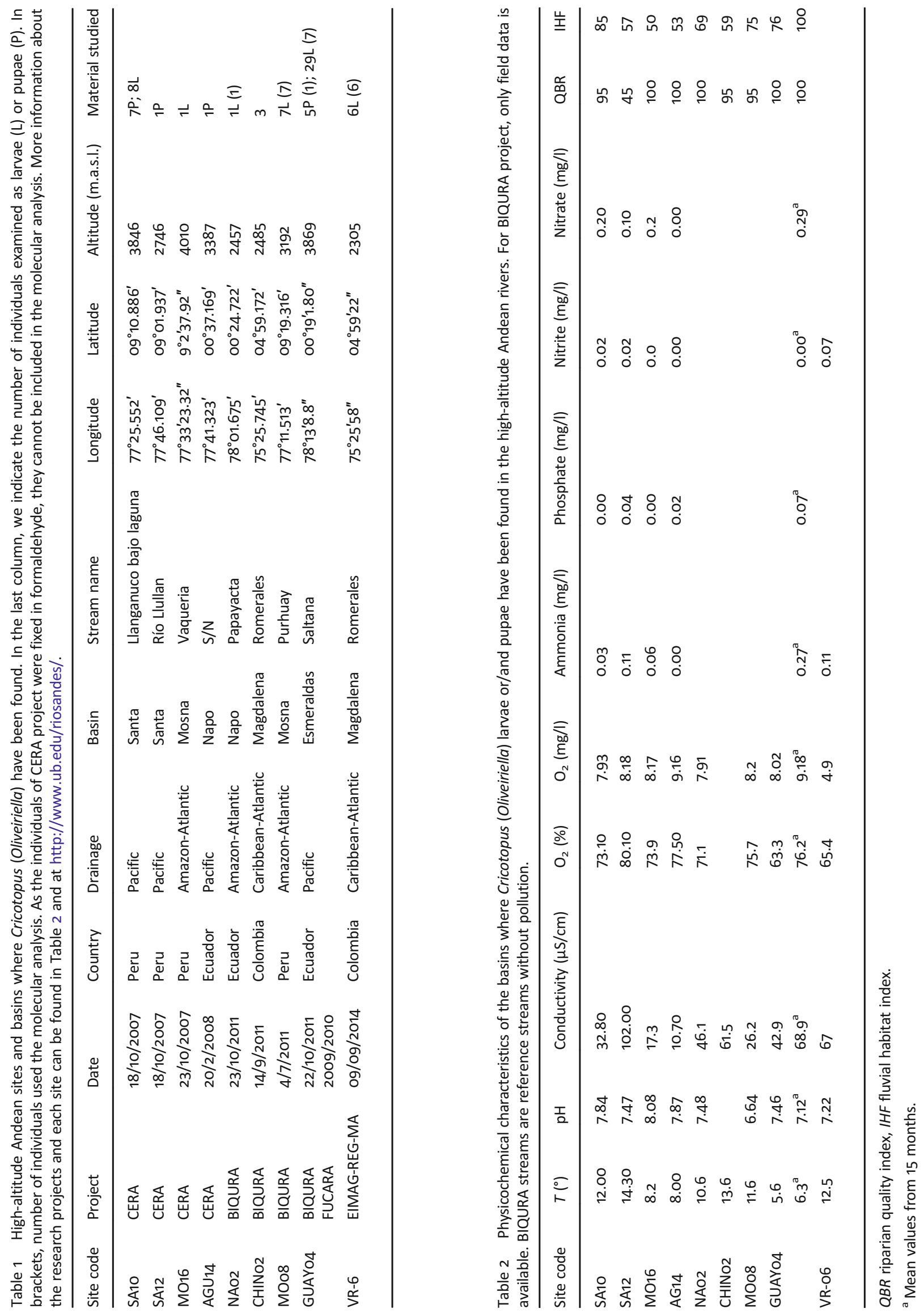
Adults were collected only at the Saltana creek (FUCARA Project), with insect traps following the methods described in Ríos-Touma et al. (2012). Three malaise traps were deployed in the river banks for $24 \mathrm{~h}$ on a monthly basis. Table 3 lists the total number of adults of $C$. (Oliveiriella) rieradevallae sp. $\mathrm{n}$. found on different dates. The studied material was preserved in $80 \%$ ethanol cleared in $10 \% \mathrm{KOH}$ and slide-mounted in Euparal ${ }^{\circledR}$ for microscopic observation, following the methods outlined in Paggi (2009). General terminology and abbreviations follow Saether (1980). Total and wing lengths are given in millimeters, and other measurements in micrometers; the measurements are given as range, followed by mean, and the number of specimens in parenthesis. Material examined was deposited at the La Plata Museum of Natural Science (MLP), La Plata, Argentina, and at the Institute of Limnology "Dr. R. A. Ringuelet" (ILPLA), La Plata, Argentina, and in the Museo Ecuatoriano de Ciencias Naturales del Instituto Nacional de Biodiversidad (MECN), Quito, Ecuador.

\section{DNA extraction, PCR amplification, sequencing, and phylogenetic analysis}

Currently, the molecular identification of species using DNAbased tools represents a successful method to assess macroinvertebrate biodiversity (especially Chironomidae) in highaltitude streams (Montagna et al 2016). In our study, total genomic DNA was extracted from samples preserved in $96 \%$ ethanol using the Qlamp ${ }^{\circledR}$ DNA Mini Kit (QIAGEN) or SPEEDTOOLS ${ }^{\circledR}$ Tissue DNA Extraction Kit (BIOTOOLS) following the manufacturer's protocol. A partial fragment of the cytochrome oxidase I (cox1) gene was selectively amplified in polymerase chain reactions (PCR) that were conducted following Krosch et al (2011), Prat et al (2013) and sequenced in the Macrogene sequence center in the Netherlands. Raw sequences were edited and assembled with Geneious 4.6.5 (Drummond et al. 2009). All new sequences obtained were deposited in GenBank for localities and GenBank accession numbers of all used samples).

Table 3 Adults of Cricotopus (Oliveiriella) rieradevallae Prat \& Paggi sp. n. caught in the Malaise traps of the river Saltana in 10 successive months.

\begin{tabular}{lll}
\hline Data & Oliveiriella & Ind/trap \\
\hline 02/10/2009 & 3f & 30.0 \\
21/10/2009 & 1f & 20.0 \\
20/11/2009 & O & 20.7 \\
$17 / 12 / 2009$ & 1m & 30.3 \\
14/01/2010 & 1m 7f & 37.7 \\
$10 / 02 / 2010$ & 1f & 35.5 \\
11/03/2010 & $9 \mathrm{~m} \mathrm{3f}$ & 63.7 \\
08/04/2010 & 1m 13f & 97.3 \\
09/05/2010 & $4 \mathrm{f}$ & 68.7 \\
08/06/2010 & O & 1.0 \\
\hline
\end{tabular}

$f$ female, $m$ male.
Alignment of the cox1 gene fragments was trivial due to the absence of length polymorphisms. Sequences were translated into amino acids, and no indels or stop codons were found. We obtained the uncorrected pairwise ( $p$ )-distance genetic divergences between terminals using MEGA v.7.0.14 (Kumar et al 2016) removing alignment gaps in pairwise comparisons. A maximum likelihood (ML) analysis was performed using RAxML 7.4.2 (Stamatakis 2006) through the graphical front-end RAXMLGUI 1.3 (Silvestro \& Michalak 2012).

$G T R+G+\mid$ nucleotide substitution model was applied, and nonparametric bootstrap support analysis of 1000 pseudoreplicates was conducted. Limnophyes species was used to root the tree.

To test if Oliveiriella is a valid genus or it is a subgenus of Cricotopus according to Andersen et al (2013), we included in the analysis several sequences of Cricotopus available at GenBank. In addition, we included in the analysis Oliveiriella almeidai from larval and pupal material collected in Argentina (see "Material and Methods" section). In Table 1, we summarized the localities of all the analyzed sites. Because some Cricotopus species appear paraphyletic with respect to some Limnophyes used as outgroup, a typology of outgroups was enforced.

\section{Results}

The species of Oliveiriella in the high-altitude Andean streams and rivers and the identity of Oliveiriella as genus: molecular data

Specimens, locality, and sequences with corresponding GenBank accession numbers analyzed in the present study are listed in Table 10 in supplementary material. The matrix used in the phylogenetic analysis includes 35 terminals and 454 aligned characters. Figure 1 shows the ML tree obtained. The genus Cricotopus appears paraphyletic with respect to the Oliveiriella species included, although with moderate bootstrap support. Within the $C$. (Oliveiriella) clade, two clusters are present. The first one is formed by $C$. (O.) almeidai plus the BIQURA samples from Peru (MOo8 samples), together with specimens from Colombia (VR-6). The uncorrected p-distances (Table 4) from O. almeidai and MOo8 plus VR-6 (12.5\%) suggest that there are two different species, while $\mathrm{MOO} 8$ and the sequences from Colombia (VR-6) must be considered as different populations of the same species (uncorrected p-distance $=2.3 \%$ ). The second cluster shows two putative species, one from river Saltana (GUAYO4) described below in this paper as $C$. (O.) rieradevallae sp. $n$. and another one from Napo River (NAO2) (uncorrected p-distance $=14.4 \%$ ) (Table 4).

In summary, Fig 1 suggests that Oliveiriella cannot be considered as a separate genus in the Orthocladiinae, but just as a subgenus of Cricotopus as indicated by Andersen et al 


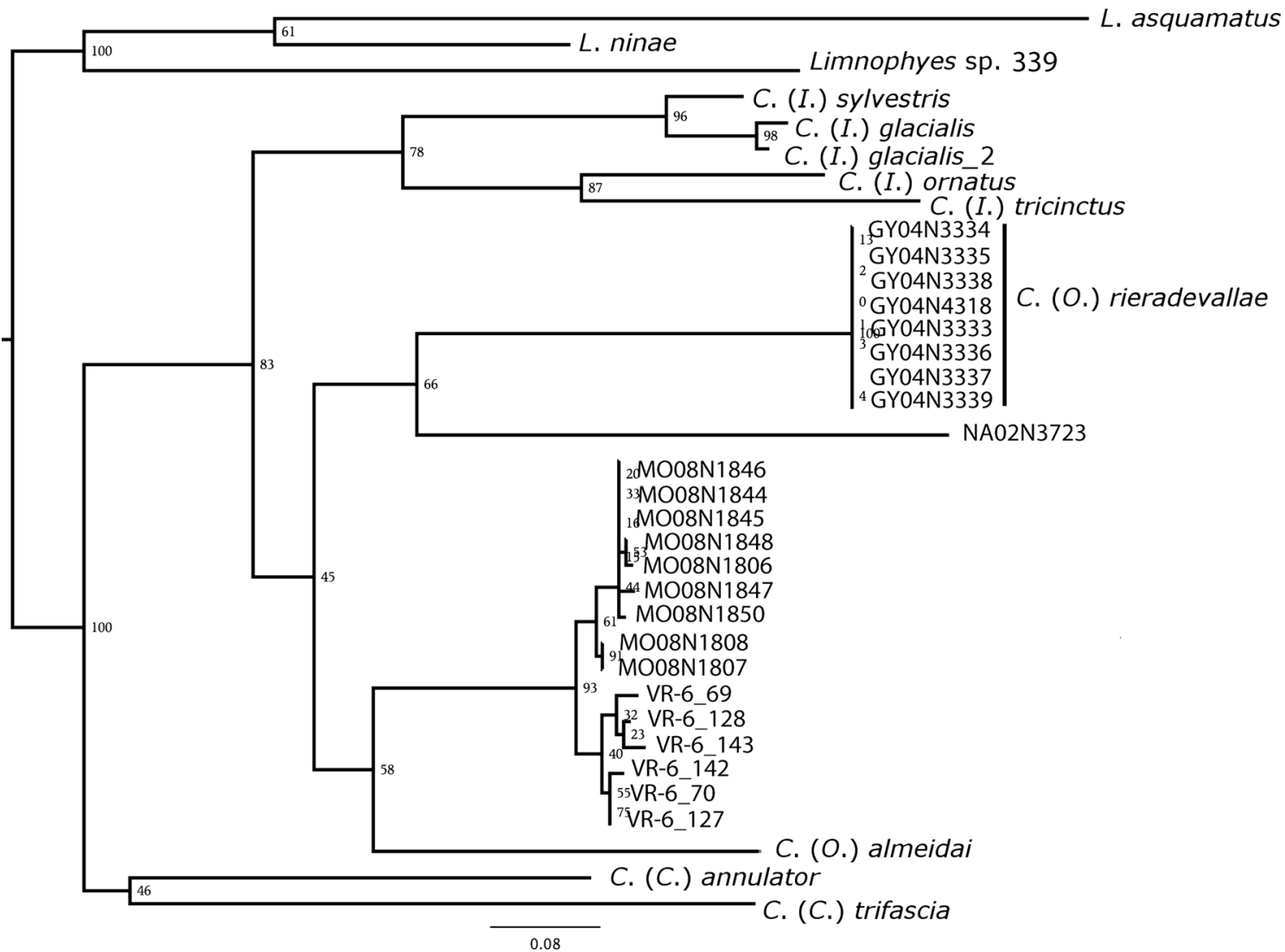

Fig $1 \mathrm{ML}$ tree of the Oliveiriella samples using partial cox1 gene sequences. Numbers in 604 nodes correspond to bootstrap support values. The tree was rooted using three Limnophyes species. Sequences of seven species of Cricotopus was also included to test the paraphyly of Cricotopus species

(2013), and there are at least four different species of the subgenus Oliveiriella in the study area.

Cricotopus (Oliveiriella) rieradevallae Prat \& Paggi new species

Type material. Holotype, male adult from Ecuador, Saltana river $00^{\circ} 19^{\prime} 1.80^{\prime \prime} \mathrm{S} 78^{\circ} 13^{\prime} 8.8^{\prime \prime} \mathrm{W}, 14 . i .2010$ leg. Blanca Ríos-
Touma, Malaise trap. Allotype, female 14.i.2010 same data as Holotype. Paratypes: same data as Holotype except for the following data: two adult males Pichincha, Res. Paluguillo, Queb. Saltana $00^{\circ} 19^{\prime} 1.80^{\prime \prime S} 78^{\circ} 13^{\prime} 8.8^{\prime \prime} \mathrm{W} 3869 \mathrm{~m}$ a.s.I. 8.iv.2010; one male adult 11.iii.2010, leg. B. Ríos-Touma \& F. González, Malaise trap; one adult female, 14.i.2010; two larvae and pupal exuviae 14.i.2010 (GYo4N3334, GYo4N3338) and 03.v.2010; two pupae 07.iv.2010 (GYo4N4318) and 05.v.2010.

Table 4 Uncorrected p-distances of cox1 partial sequences between species analyzed in this study.

GYo4 NAO2 MOO8 \& VR-6 O. almeidai C. glacialis $\quad$ C. annulator $\quad$ C. trifascia $\quad$ C. glacialis_2 $\quad$ C. ornatus $\quad$ C. sylvestris

\section{GUAYO4}

$\mathrm{NAO2}$

0.144

MOO8 \& VR-6

$0.119 \quad 0.150$

C. (O.) almeidai $\quad 0.139 \quad 0.151$

C. (I.) glacialis $\quad 0.162 \quad 0.162 \quad 0.129$

C.(C.) annulator

$\begin{array}{lll}0.174 & 0.183 & 0.153\end{array}$

C.(C.) trifascia

$\begin{array}{llll}0.178 & 0.178 & 0.150\end{array}$

C. (I.) glacialis_2 $\quad 0.165 \quad 0.162 \quad 0.125$

$\begin{array}{llll}\text { C. (I.) ornatus } & 0.162 & 0.167 & 0.144\end{array}$

C. (I.) sylvestris

$\begin{array}{lll}0.160 & 0.167 & 0.131\end{array}$

C. (I.) tricinctus

$\begin{array}{lll}0.158 & 0.169 & 0.142\end{array}$

$\begin{array}{lll}0.139 & & \\ 0.155 & 0.155 & \\ 0.182 & 0.175 & 0.154 \\ 0.144 & 0.014 & 0.151 \\ 0.158 & 0.130 & 0.155 \\ 0.128 & 0.049 & 0.132 \\ 0.144 & 0.132 & 0.146\end{array}$

$\begin{array}{ll}0.171 & \\ 0.168 & 0.130 \\ 0.175 & 0.044 \\ 0.189 & 0.132\end{array}$

0.116

0.102 0.123 
Diagnostic characters. Male, female, and preimaginal stages of $C$. (O.) rieradevallae $\mathrm{sp}$. $\mathrm{n}$. are differentiated from $C$. (O.) almeidai n. comb. and $C$. (O.) sanjavieri n. comb. by the following characters:

Adults. The male can be distinguished from the other two species of subgenus Oliveiriella described until now by having a total length of 3.60 mm; 8-9 clypeus setae; 45-60 setae in the scutellum and 7-10 squamal setae (Table 5). Alar spot in the anal cell absent (in $C$. (O.) sanjavieri is present, Fig $2 b$ ). Legs with 67-71 comb teeth in hind tibia; fore and mid tibia white band ratio (BR) 0.35 and 0.27 , respectively (Fig 2c, e); hind leg completely dark (Fig $2 \mathrm{~g}$ ). This color pattern in the legs is different compared with $C$. (O.) sanjavieri (Fig $2 \mathrm{~d}, \mathrm{f}$ ). The female can be distinguished from the other two species by having a total length of $3.42 \mathrm{~mm}$; 11-14 clypeal setae, 20 acrostichal setae; 60-68 scutellar setae; the band ratio on fore and mid tibia and the wings with the same characteristic as in males (Table 5).

Pupae. C. (O.) rieradevallae from river Saltana is larger than the other two species (Tables 5 and 8). Length of the respiratory organ (OR) 240-273 $\mu \mathrm{m}$ and with a clear terminal notch and its entire surface serrated (Fig 3a). The medial precorneal setae are more than 10 times longer than the anterior and posterior (Fig 3a, b) compared with $C$. (O.) sanjavieri, of which the length of the median precorneal setae is at most three times longer than the other two setae, whereas C. (O.) almeidai (Brazil) of which all the setae are of similar size (Table 5). This is also true with the first and third dorsocentral setae of the cephalothorax which are much longer than the second one (Fig 3 b) (in C. (O.) sanjavieri are of similar length). The abdomen (Fig $3 \mathrm{C}-\mathrm{g}$ ) has much longer lateral setae than those of $C$. (O.) almeidai but shorter than those of $C$. (O.) sanjavieri. Cricotopus (Oliveiriella) rieradevallae has characteristic spines in the sternites II and III that lack in the other two species found until now (Fig 3d, e).

Larvae. The only characters that seem to differentiate $C$. (O.) rieradevallae from the other species are the higher $\mathrm{AR}$, major length of the antennal blade, and a higher MR (Tables 5 and 9). The presence of transversal marks in the mentum is characteristic of all the Andean high-altitude river species (Fig 4b). The pattern of small dots of the head capsule is also very conspicuous and both (marks and the pattern) facilitated the distinction of the Oliveiriella larvae from the Andean high-altitude rivers from the other subgenera in the Cricotopus group and especially from Genus 1 sensu Roback \& Coffman (1983).

\section{Description (Fig 2)}

Male imago. ( $n=4$, except when otherwise stated). Total length 3.42-3.78, 3.60; wing length 2.00-2.49, 2.44; total length/wing length 1.43-1.52, 1.47; wing length/length of profemur 2.68-2.87, 2.78. General coloration dark brown, almost black. Thorax and abdomen dark brown. Wing with brown areas almost reaching $\mathrm{M}_{3+4}$ and without a spot in the
Table 5 Distinctive characteristics of the three species of Cricotopus (Oliveiriella) known from Neotropical region.

\begin{tabular}{llll}
\hline & C. (O.) almeidai & C. (O.) sanjavieri & C. (O.) rieradevallae \\
\hline Male & & & \\
Wing length (mm) & 1.09 & $1.9-2.43$ & $2.0-2.49$ \\
Clipeus setae & 12 & $14-16$ & $8-9$ \\
Scutellum setae & 12 & 18 & $45-60$ \\
Squamal setae & 5 & $7-9$ & $7-10$ \\
Comb teeth in the hind tibia & & $57-60$ & $67-71$ \\
Fore and mid tibia with band ratio & $<1 / 2$ & $<1 / 2$ & $>1 / 2$ \\
Hind leg & Brown to yellow & Brown to yellow & Dark \\
Alar spot in the anal cell & Absent & Present & Absent \\
Pupae & & & $3.22-3.82$ \\
Body size (mm) & $2.2-2.8$ & $2.41-3.19$ & $240-273$ \\
RO length ( $\mu \mathrm{m})$ & $136-242$ & $220-280$ & Present \\
RO notch & Absent & Absent & $>8$ \\
Medial/anterior precorneal seta size & 1 & 3 & $>7$ \\
1st and 3rd/2nd dorsocentral setae & 1 & 1 & Present \\
Spines in sternites II and III & Absent & Absent & $3.1-3.73$ \\
Larvae & & & $1.83-1.89$ \\
Size & $2.7-3.2$ & $3.4-4.02$ & $1.16-1.88$ \\
AR & $1.4-1.8$ & &
\end{tabular}

$R O$ respiratory organ, $A R$ antennal ratio. 


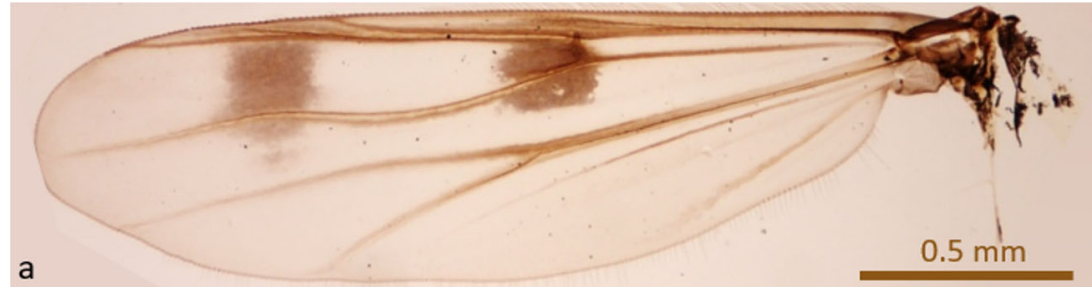

Fig 2 Cricotopus (Oliveiriella) rieradevallae Prat \& Paggi sp. $\mathrm{n}$. adult. a Wing. c PI. e PII. g PIII. Cricotopus (Oliveiriella) sanjavieri adult. b Wing. d PI. f PII.

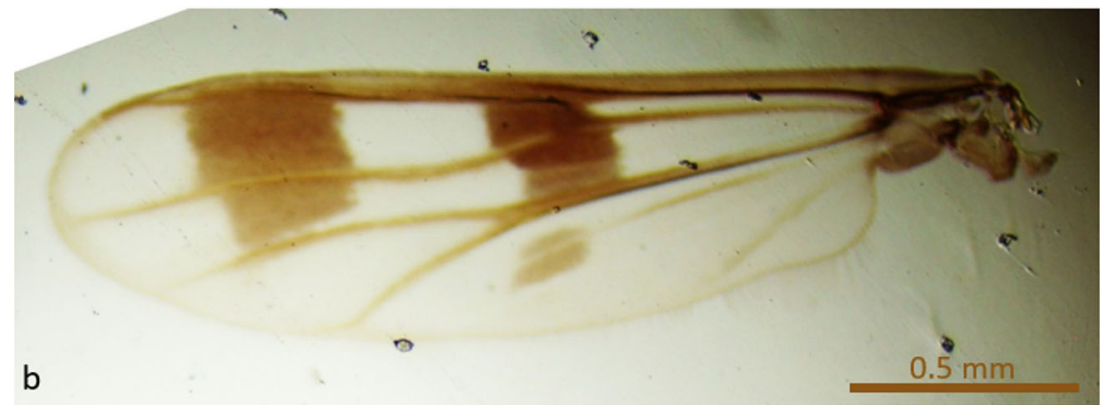

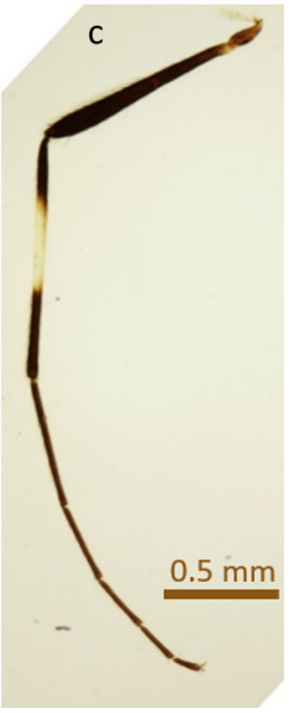

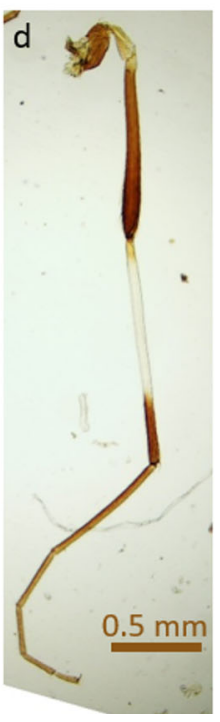

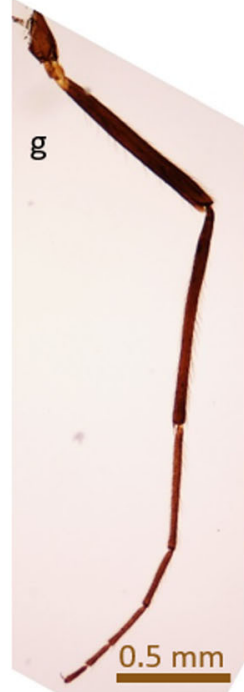

anal cell (Fig 2a), abdomen and leg coloration pattern as generic diagnosis.

Head. Temporal setae 4-5, 5. Clypeus with 8-9, 8 (3) setae. Tentorium 136-152, 141 long; palpal segment length (1-4): 20, $25,45,60$, fifth segment not measurable (1).

Thorax. Acrostichals 16-18 (2); dorsocentrals 20 (1); prealars 3; scutellars 45-60, 60 (3).

Wing. VR 1.14-1.20, 1.17; C/WL 0.90-0.92, 0.91; Cu/WL 0.43$0.44,0.43$. Costa extended beyond $R_{4}+575-83,81$ Cu slightly curved. Squama with 7-10, 9 setae.

Legs. With a white band (WB) on fore and mid tibiae covering less than half of each tibia in a ratio of (WB/ $\left.\mathrm{Ti}_{1}\right) 0.40-0.29,0.35(3)$ and $\left(\mathrm{WB} / \mathrm{Ti}_{2}\right) 0.23-0.32,0.27$ (3)

(Fig 2c, e, g). Tibial spur of fore leg 45-51, 48 long; spurs of mid tibiae 20-22 and 16 long; spurs of hind tibia: 6771, 70 and 20-22, 22 long, comb with 13-15, 14 teeth. Sensilla chaetica 5 (1) on hind $\mathrm{Ta}_{1}$. Pulvilli absent. Length and proportions of legs as in Table 6.

Abdomen. Chaetotaxy: TI with an anterolateral group of about 12 setae and distal group of 3-4 dorsal setae, TII-IV with 2 median setae and a transverse row of about 10 dorsal setae; TV-VI with a median longitudinal row of 10-12 setae; TVII-VIII with a central patch of 20-30 irregular distributed setae. TII-VIII each with 5 lateral setae.

Genitalia. Hypopygium. Gonocoxite 207-224, 207 long; gonostylus 75-83, 77 long. Tergite IX with 6-10 dorsal setae. Laterosternite 3-4 setae. Megaseta 8-10, 9 long. HR: 2.562.78, 2.70. HV: 4.30-5.07, 4.69. 

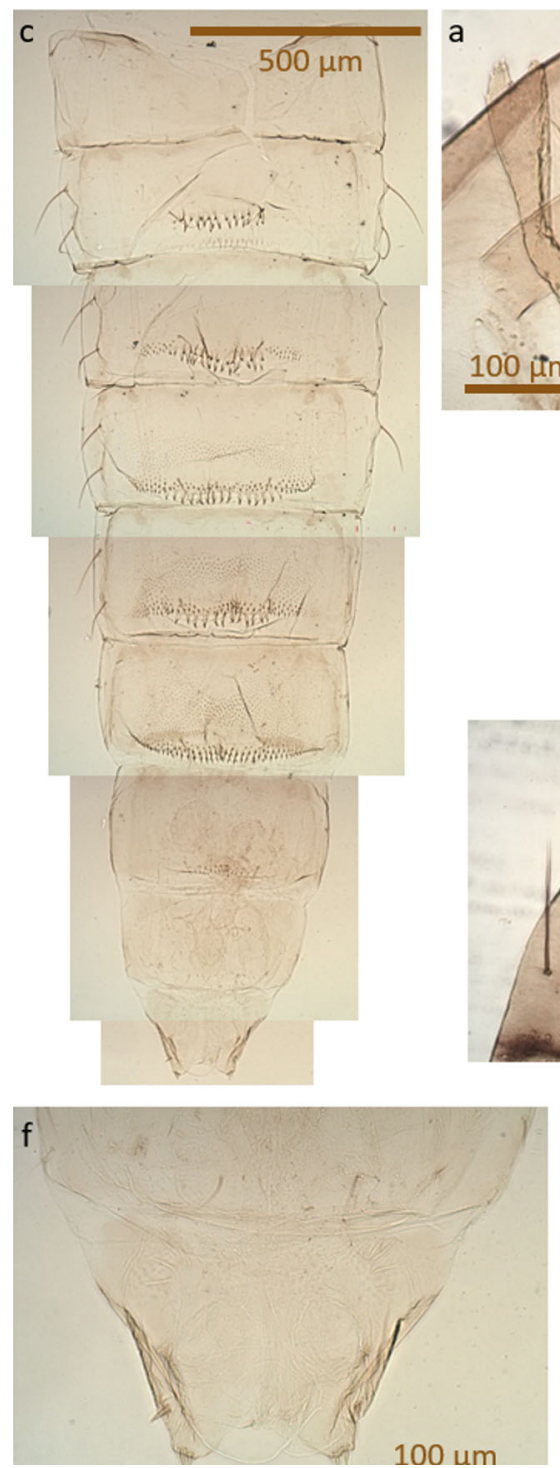
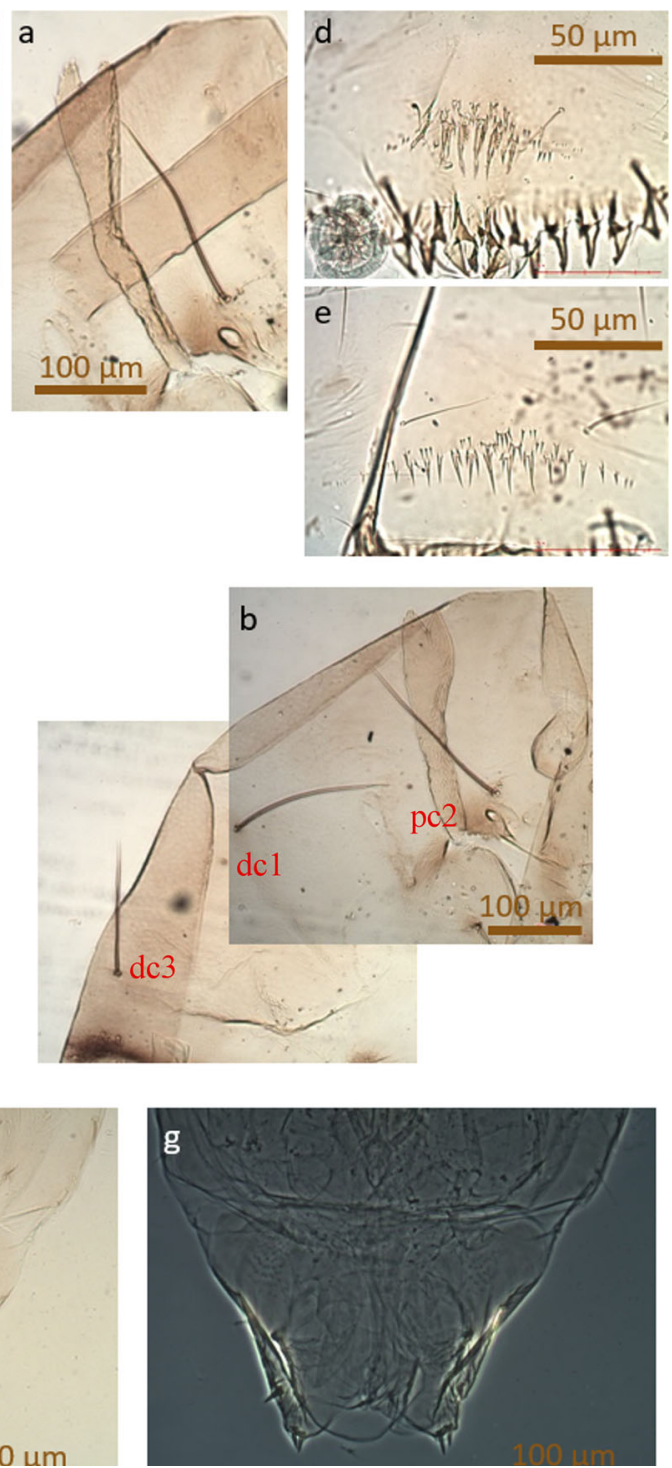

Fig 3 Cricotopus (Oliveiriella) rieradevallae Prat \& Paggi sp. $\mathrm{n}$. Pupae: a Respiratory organ; $\mathbf{b}$ Thorax with long dorsocentral and precorneal setae ( $\mathrm{dc1}, \mathrm{dc} 3$ and pc2); $\mathbf{c}$ Abdomen; $\mathbf{d}$ Spines of sternite II; e Spines of sternite III; f Abdominal segment IX; g) Abdominal segment IX (phase contrast).
0.27 . Tibial spur of fore leg 34-38 long; spurs of mid tibiae 20 and 14 long; spurs of hind tibia: 61-75 and 22-24 long, comb with 13-14 teeth. Pulvilli absent. Sensilla chaetica 10 on middle $\mathrm{Ta}_{1}$ and $8-10$ on hind $\mathrm{Ta}_{1}$. Length and proportions of legs listed in Table 7.

Abdomen. Distribution of setae as in male. S VI-VII with a central patch of about 20-22 setae.

Genitalia. Gonocoxite IX with 6-8 setae; tergite IX with 7 setae; sternite VIII with 11-16 setae. Seminal capsule ovate, light brown, 112-165 long, 83-122 wide, with long ducts, at least with one loop. Notum 190 long. Cerci 69-81 long.

Pupa. ( $n=4$, except when otherwise stated, measurements of additional material are in Table 8). Total length 3.22-3.82, 3.48 .

than half of each tibia, in a ratio of $\left(\mathrm{WB} / \mathrm{Ti}_{1}\right) 0.31$ and $\left(\mathrm{WB} / \mathrm{Ti}_{2}\right)$ 
Cephalothorax. (Fig 3a, b). Precorneals: anterior 22-24, median 193-207, posterior 18-24 $\mu \mathrm{m}$ long. Dorsocentrals first and third 149-157 long, second and fourth approximately 20 long (2) (Fig 3b). Thoracic horn 240-273 (2) long apically truncated with a median notch and surface serrated as in Fig $3 a$.

Abdomen. (Fig 3c-g). Tergite II with two posterior rows of each 12-15, 13 hooklets. TIII with two rows of each 11-15, 14 hooklets and small spinules on either side of these rows connected to a central shagreen. TIV-V with 1 posterior row of 9-13, 12 hooklets, and small spines anteriorly also connected to shagreen (Fig $3 \mathrm{C}$ ). TVI with a posteromedian group of small spinules and a row of moderately 12 strong spines. TVII-VIII with a posteromedian patch of spinules. TVIVII with posteromedian fine shagreen. Abdominal segments: I with one strong lateral setae 121 long; II-V with two strong lateral setae 124-141 long on small tubercles. Tergites II-VIII with a pair of strong $D_{5}$ near hind margin. Sternites with ventromedian patches of spinules (Fig $3 d, e$ ). Anal lobe with 3 very short spine-like anal macrosetae (Fig $3 f, g$ ) length and distance between spines in Table 8).

Larva. ( $n=2$, except when otherwise stated, measurements of additional material are in Table 9). Total length 3.31-3.73. Body color (live) with intense blue and white bands, dark brown when fixed (Fig 4c).

Head. (Fig 4a, b). 415-519 long; 519 wide when mounted on slides. Postmentum 207 long. Head dark brown rugulose with pale spots around the eyes, and the gula more dark, with a pattern of small dots and several transversal marks between and below the mentum.

Antenna. (Fig 4C, d). Basal antennal segment 53-55 long; segments (2-5): 14-16; 6; 4; 4 long. AR 1.83-1.89. Blade 41 long. Ring organ at 6.09 from base of basal antennal segment.

Mentum. (Fig 4b). Median tooth twice as wide as the first lateral tooth (Table 9). Second lateral tooth smaller and narrower than the rest of the lateral teeth, sixth lateral tooth very small. Seta submenti simple and lateral, close to the base of the mentum.

Mandible. (Fig 4c). Dark brown with 4 inner teeth, with rugose outer margin, 142-148 long. Premandible simple.

Abdomen. (Fig 4e). Long and simple setae (at least half of the segment wide). Posterior parapod 207 long, 116-133 wide. Procerci 14-20 long; 24-28 wide. Anal tubules 331-373 long, longer than posterior parapods.

Etymology. This species is named in memory of the late Maria Rieradevall, a distinguished ecologist and 
Table 7 Lengths (in $\mu \mathrm{m}$ ) and proportions of legs of Cricotopus (Oliveiriella) rieradevallae Prat \& Paggi sp. n. (females $n=2$ ).

\begin{tabular}{lllllllllll}
\hline & $\mathrm{Fe}$ & $\mathrm{Ti}$ & $\mathrm{Ta}_{1}$ & $\mathrm{Ta}_{2}$ & $\mathrm{Ta}_{3}$ & $\mathrm{Ta}_{4}$ & $\mathrm{Ta}_{5}$ & $\mathrm{LR}$ & $\mathrm{BV}$ & $\mathrm{SV}$ \\
\hline $\mathrm{P}_{1}$ & $851-913$ & $955-1038$ & $498-560$ & $311-353$ & $228-249$ & $166-187$ & $104-125$ & $0.52-0.54$ & $2.75-2.85$ & $3.48-3.63$ \\
$\mathrm{P}_{2}$ & $768-851$ & $789-872$ & $332-394$ & $187-208$ & $145-165$ & 104 & 104 & $0.42-0.45$ & $3.5-3.64$ & $4.37-4.69$ \\
$\mathrm{P}_{3}$ & $809-913$ & $934-1017$ & $498-540$ & $249-270$ & $208-228$ & $104-125$ & $104-125$ & 0.53 & $3.31-3.38$ & $3.50-3.58$ \\
\hline
\end{tabular}

$P 1$ fore leg, $P 2$ mid leg, $P 3$ hind leg, Fe femur, Ti tibia, Ta tarsus, $L R$ leg ratio (length of $T a_{1} /$ length of tibia), $B V$ length of (femur + tibia $\left.+T a_{1}\right) / l$ length of $\left(T a_{2}+T_{3}+T_{4}+T a_{5}\right)$, SV length of (femur + tibia)/length of Ta.

chironomidologist, and a founding member of the F.E.M. research group.

\section{Distribution of Cricotopus (Oliveiriella) spp. in the high Andean tropical rivers}

Larvae, pupae, or pupal exuviae of Oliveiriella were found in a total of nine sites from southern Peru to northern Colombia
(Table 1). The number of larvae and/or pupae found in each site was always low ( 1 to 20 individuals, Table 1 ) in streams of low ( $1 \mathrm{~m}$ wide) to medium $(8 \mathrm{~m})$ size and in a range of altitudes from 2308 to $4431 \mathrm{~m}$ a.s.l. Stones are the dominant substrate of many of the rivers and some of them have a considerable slope (up to $16 \%$ ).

Conductivity of the streams was low from 10 to $100 \mu \mathrm{S} / \mathrm{cm}$ temperature between 5,6 , and $14^{\circ} \mathrm{C}$ and $\mathrm{pH}$ mostly neutral
Table 8 Morphometric characteristics of the pupae of Cricotopus (Oliveiriella) found in the high tropical Andean rivers. Unless indicated, data are in microns and correspond to the length of the character. Site characteristics are in Tables 1 and 2 .

\begin{tabular}{|c|c|c|c|c|c|}
\hline $\begin{array}{l}\text { Site } \\
\mathrm{n} \\
\text { Project }\end{array}$ & $\begin{array}{l}\text { SA10 } \\
7 \\
\text { CERA } \\
\text { Mean }\end{array}$ & $\begin{array}{l}\text { SA12 } \\
1 \\
\text { CERA }\end{array}$ & $\begin{array}{l}\text { AGU14 } \\
1 \\
\text { CERA }\end{array}$ & $\begin{array}{l}\text { CHINO2 } \\
3 \\
\text { BIQURA } \\
\text { Mean }\end{array}$ & $\begin{array}{l}\text { GUAYO4 } \\
5 \\
\text { BICURA/FUCARA } \\
\text { Mean }\end{array}$ \\
\hline Th L & $929(889-945)$ & 863 & 863 & 943 (917-992) & 1053 (1030-1099) \\
\hline$A b L$ & 2199 (2173-2274) & 2267 & 2292 & 1946 (1853-2014) & $2663(2552-2801)$ \\
\hline L Dc setae 1 & 175 (16o-194) & 201 & 202 & $50(41-62)$ & 178 (160-194) \\
\hline L Dc setae 2 & $34(22-58)$ & 63 & 18 & $49(42-59)$ & $34(14-52)$ \\
\hline L Dc setae 3 & 159 (143-189) & 165 & 183 & $41(34-46)$ & 161 (149-172) \\
\hline L Dc setae 4 & $23(18-28)$ & & 33 & $27(21-35)$ & $21(13-39)$ \\
\hline L Prec setae 1 & $49(41-57)$ & 57 & 51 & $69(59-74)$ & $43(35-54)$ \\
\hline L Prec setae 2 & $196(187-207)$ & 209 & 200 & $80(77-83)$ & $216(184-244)$ \\
\hline L Prec setae 3 & $45(35-59)$ & 39 & 42 & $49(46-52)$ & $26(14-39)$ \\
\hline RO L & $226(220-232)$ & 193 & 133 & $249(233-275)$ & $296(273-314)$ \\
\hline RO W & $43(26-53)$ & 57 & 20 & $42(24-62)$ & $65(55-84)$ \\
\hline HR T-II (n) & $10(8-11)$ & 6 & 10 & $14(14-15)$ & $13(12-15)$ \\
\hline HR T-III (n) & $12(10-14)$ & 8 & 10 & $14(14-15)$ & $14(11-15)$ \\
\hline HR T-IV (n) & $11(8-14)$ & 9 & 8 & $12(11-13)$ & $13(9-17)$ \\
\hline HR T-V (n) & $10(8-13)$ & 9 & 11 & $11(10-11)$ & $12(9-13)$ \\
\hline L Ab setae $\mathrm{S}-\mathrm{II}$ & $128(112-137)$ & 138 & 146 & $106(95-112)$ & $147(138-156)$ \\
\hline L Ab setae S-III & $122(114-133)$ & 132 & 145 & 118 (115-121) & 149 (132-159) \\
\hline L Ab setae S-IV & $127(112-138)$ & 133 & 136 & $118(122-118)$ & $137(124-153)$ \\
\hline Sp S-II (n) & No/small & Small & 8 & No & $8(4-13)$ \\
\hline Sp S-III (n) & No/small & Small & 6 & No & $9(8-13)$ \\
\hline L AS setae 1 & $20(18-22)$ & 12 & 18 & $17(15-20)$ & $16(14-23)$ \\
\hline L AS setae 2 & $19(15-21)$ & 11 & 19 & $13(11-16)$ & $20(18-23)$ \\
\hline L AS setae 3 & $19(15-21)$ & 11 & 18 & $21(19-25)$ & $18(16-23)$ \\
\hline AS distance $2-3$ & $12(8-15)$ & 7 & 11 & $22(15-27)$ & $9(8-11)$ \\
\hline AS distance 1-2 & $26(17-40)$ & 16 & 31 & 36 (29-44) & $45(33-73)$ \\
\hline
\end{tabular}

$L$ length, $W$ wide, $n$ number, $T h$ thorax, $A b$ abdomen, $D c$ dorsocentral, Prec precorneal, $S p$ spine, $T$ tergite, $S$ sternite, $R O$ respiratory organ, $H R$ hook row, $A S$ anal segment. 
Table 9 Morphometric characteristics of the larvae of Cricotopus (Oliveiriella) in the high tropical Andean rivers. Unless indicated, data are in microns and correspond to the length of the character. Site characteristics are in Tables 1 and 2.

\begin{tabular}{|c|c|c|c|c|c|c|}
\hline \multicolumn{2}{|l|}{ Site } & SA10 & M016 & M008 & NAPOO2 & GUAYO4 \\
\hline \multicolumn{2}{|l|}{ Project } & CERA & CERA & BIQURA & BIQURA & BIQURA/FUCARA \\
\hline \multicolumn{2}{|l|}{$\mathrm{n}$} & 8 & 1 & & 1 & \\
\hline \multirow[t]{2}{*}{ Head cap } & L & 406 (391-412) & 368 & $397(373-418)(n=4)$ & 390 & $461(430-493)(n=16)$ \\
\hline & W & $311(293-320)$ & 306 & $335(307-359)(n=4)$ & 291 & $379(349-403)(n=16)$ \\
\hline \multicolumn{2}{|c|}{ Postmentum } & $186(165-198)$ & 184 & $185(174-198)(n=7)$ & 185 & $220(201-230)(n=29)$ \\
\hline \multirow[t]{8}{*}{ Antenna } & Basal L & $44(41-48)$ & 42 & $46(44-50)(n=7)$ & 43 & $56(49-63)(n=28)$ \\
\hline & II L & $13(11-16)$ & 15 & $14(12-16)(n=7)$ & 12 & $15(12-16)(n=28)$ \\
\hline & III L & $6(5-7)$ & 7 & $5(5-7)(n=6)$ & 5 & $6(4-8)(n=25)$ \\
\hline & IV L & $5(3-5)$ & 5 & $5(4-5)(n=6)$ & 5 & $4(3-6)(n=24)$ \\
\hline & V L & $3(2-4)$ & 3 & $3(2-4)(n=4$ & 2 & $3(2-4)(n=10)$ \\
\hline & AR & $2(1-2)$ & 1 & $2(1-2)(n=4)$ & 2 & $2(2-3)(n=24)$ \\
\hline & $A B L$ & & & $27(22-32)(n=4)$ & & $25(19-33)(n=10)$ \\
\hline & LO L & & & $9(9-9)(n=2)$ & & $8(7-10)(n=5)$ \\
\hline Mentum & W & $110(106-125)$ & 106 & $112(103-115)(n=6)$ & 108 & $118(104-137)(n=25)$ \\
\hline M1 & W & $16(13-18)$ & 17 & $17(17-20)(n=6)$ & 15 & $21(18-29)(n=26)$ \\
\hline $\mathrm{M} 2$ & W & $8(7-9)$ & 8 & $8(8-9)(n=7)$ & 8 & $8(7-11)(n=26)$ \\
\hline \multicolumn{2}{|c|}{ MR (M1/mentum) } & $0.14(0.12-0.17)$ & 0.16 & $0.157(0.146-0.162)(n=5)$ & 0.14 & $0.17(0.14-0.25)(n=25)$ \\
\hline
\end{tabular}

$L$ length, $W$ wide, $A R$ antennal ratio, $A B$ antennal blade, $L O$ lauterborn organs.

(Table 2). Oxygen levels were always over 60\% saturation with values over $7.91 \mathrm{mg} / \mathrm{l}$. All the streams are oligotrophic with low concentrations of pollutants, including heavy metals. For more details of the physicochemical characteristics of these rivers, see also Villamarín et al (2014). Project BIQURA samples were collected from reference areas, sites without or with low human disturbance; therefore, although some parameters were not measured in BIQURA, the water quality of these streams was good. Sometimes the heterogeneity of substrates in the river may be low (as indicated by the values of IHF lower than 50 in Table 2), and the riparian area may be impacted (values of QBR-And lower than 75, Table 2). Values of QBR-And may be lower than expected for a reference site, due to the absence of a true riparian forest in the high-altitude streams (Acosta et al 2009, Acosta \& Prat 2010).

\section{Morphological variability of larvae and pupae of high-altitude Andean Cricotopus (Oliveiriella) species}

Larvae. Live larvae of Oliveiriella of river Saltana were quite unique for its body color (blue and white), the intense black head capsule and the very long anal tubules (up to 395) that are more than double the length of the posterior parapods (Fig 4e). In living samples, these two characteristics made Oliveiriella easily recognizable under the stereoscope at low $(\times 10)$ magnification. When fixed, the larvae lost the color but still the long anal tubules and the presence of body setae, with a length close to half of the segment wide, made the larvae distinctive in the stereoscope. However, the larvae may lose the anal tubules when treated with $\mathrm{KOH}$, which may create some confusion if only slide material is studied. Some of the larval head characteristics are similar to larvae of individuals of the genera comprised in the Cricotopus group (including the bifid SII, the crenulations in the mandible, or the general form of the mentum), but the head capsule of Oliveiriella offers some characteristic features that allow us to distinguish these larvae from the rest of the Cricotopus group. The color of the head is brown with a pattern of small dots. In the mentum and postmentum, there several line marks, which are characteristic (Fig $4 \mathrm{~b}$ ). Distinction of the larvae of different members of the Cricotopus complex in the Andes may be found in Prat et al (2012).

According to Andersen et al (2013), larvae of Cricotopus (Oliveiriella) have yellow to light brown head capsules, which is not the case of the $C$. (Oliveiriella) larvae of the Andes that have a dark brown head. The same authors include $C$. (Oliveiriella) in the group of species with setal tufs and the outer margin of the larvae completely smooth, which is not true in the larvae from the Andes (that wear simple setae and have a rugose outer margin of the mandible) and that otherwise have transversal marks in the gula that are characteristic as well as are the long anal tubules. In fact, in the paper of Krestian et al (2009), there is a figure of the mentum of Oliveiriella (Fig 3a) where it can be seen that the 

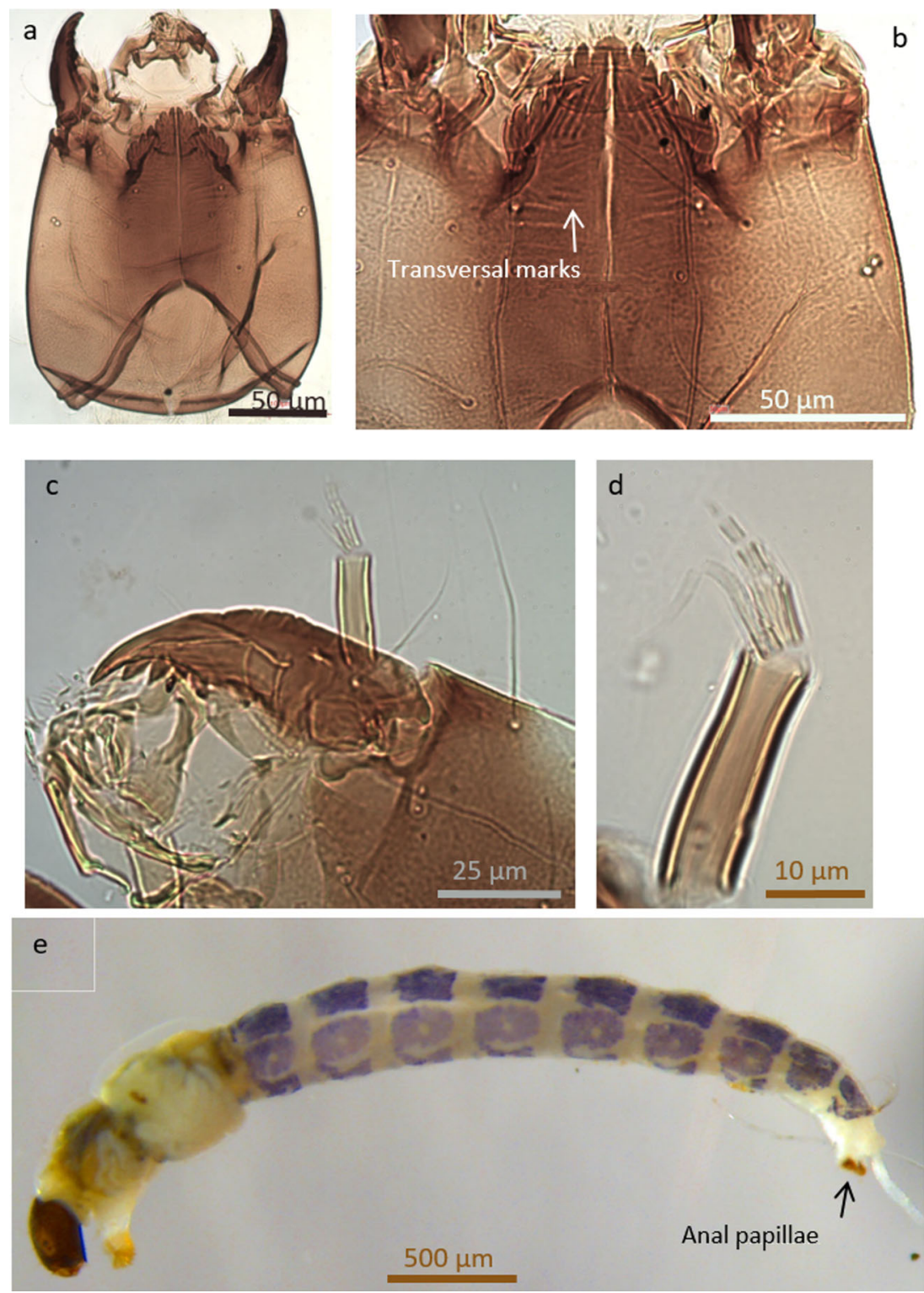

Fig 4 Cricotopus (Oliveiriella) rieradevallae Prat \& Paggi sp. $\mathrm{n}$. larvae. a Head capsule. b Mentum. c Mandible. d Antennae. e Larvae showing the long papillae (picture: Paula Ossa).

mentum is dark and with striae similar to those of ours Fig 4b. The key of Andersen et al (2013) should be consequently changed to allow the distinction of the Oliveiriella subgenus members from the genus Cricotopus.

After measuring a total of 50 larvae from five sites, some differences appear between the larvae of site GUAYO4 (Saltana) and the other sites. Larvae of the GUAYo4 site are larger, with a higher AR and MR than the other larvae, which are very similar. We use the measure of postmentum as a measure of size of the larvae (see Table 9) because in the slides, the head capsule larval length and width may depend on the position of the larvae and the pressure applied during the preparation of the slide.

Pupae. The pupae of Oliveiriella are very characteristic, as described by Wiedenbrug \& Fittkau (1997) and Tejerina \& Paggi (2009) and very different from any species of the group Cricotopus as can be seen in the key of pupae or Prat et al (2014). The presence of hook rows (HR) in the segments II to $\mathrm{V}$ is characteristic, as well as the size and shape of the three setae of the anal segment that are transformed in small spines (Fig 3f, g). In Table 8, we compare the characteristics of the Cricotopus (Oliveiriella) pupae and pupal exuviae found in the 

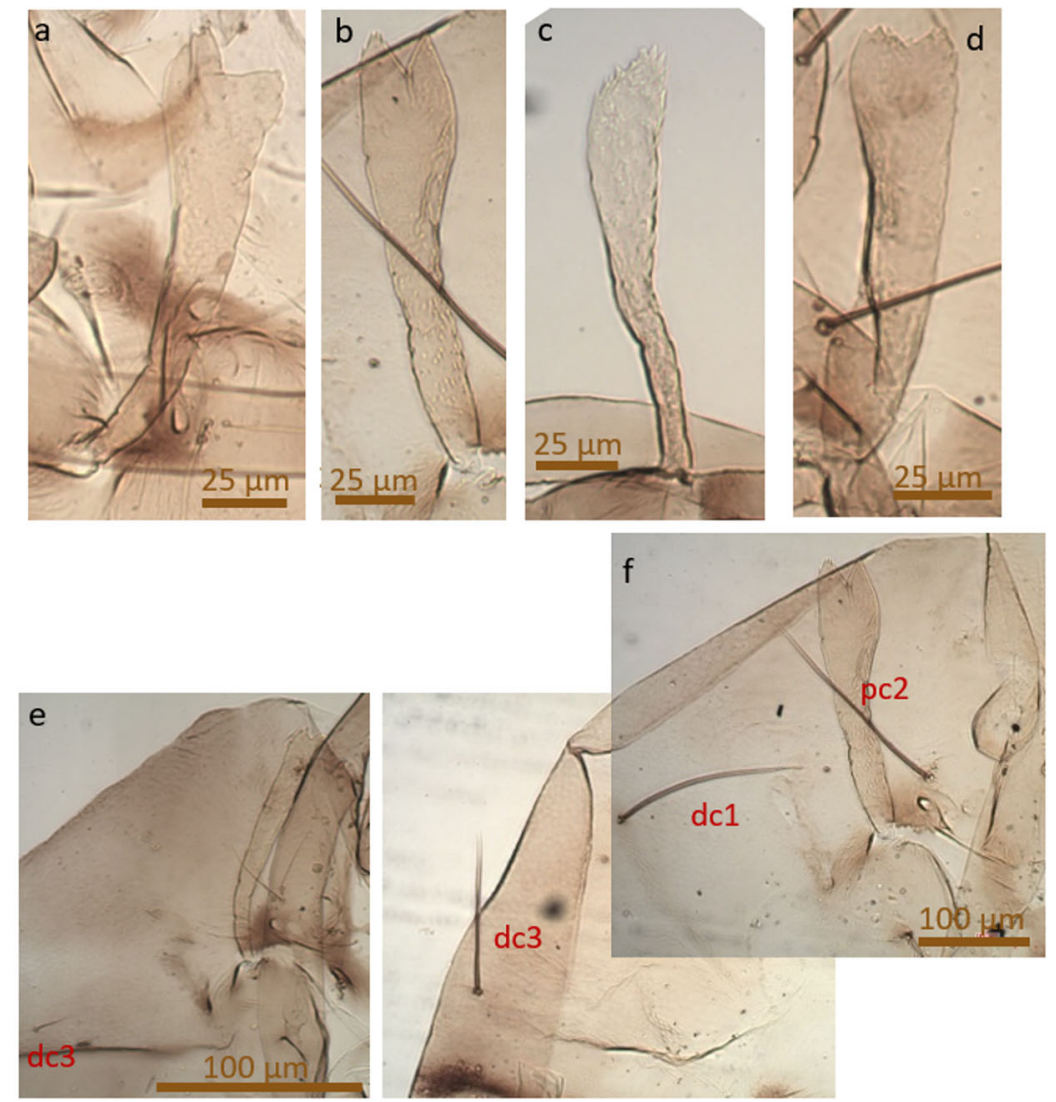

Fig 5 Cricotopus (Oliveiriella) spp. pupae. Respiratory organ: a CHINO2 (Colombia), b GUAYO4 (Ecuador), c AGU14 (Ecuador), d SA10 (Peru). Thorax: e CHINO2 (short dorsocentral and precorneal setae), f GUAYo4. Abdominal segment IX: $\mathbf{g}$ GUAY04, h SA10. In red the distance between the AS1 and AS2 (see Table 8).
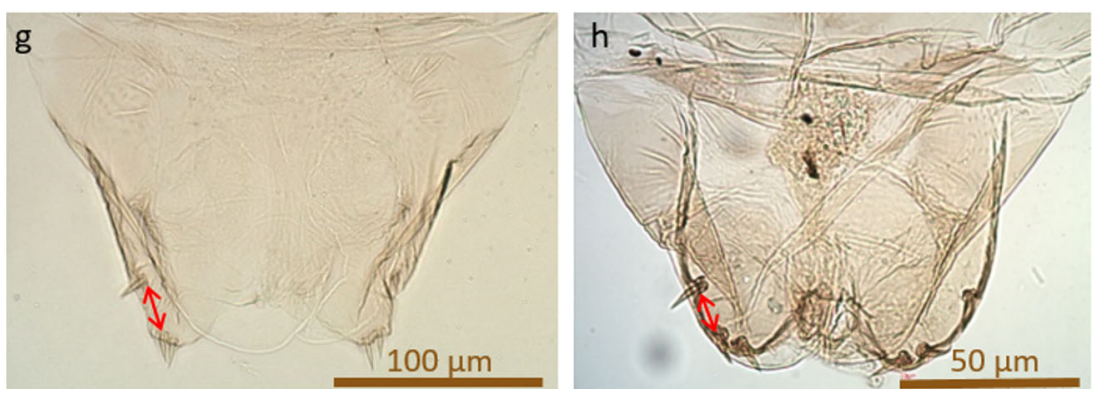

tropical Andean high-altitude streams (5 sites, 19 individuals). There are two different groups of species easily recognizable by the difference of length of precorneal medium setae and the length of dorsal setae 1 and 3 with respect to the dorsal seta 2 (Tables 5 and 8). In the first group, only one specimen appeared in the CHINO2 site (from Chinchiná River). Pupae at this site have both the precorneals and dorsal setae of similar length as in $C$. (O.) almeidai and C. (O.) sanjavieri, although the setae are shorter (41 to 49 in CHINO2 vs 109 in C. (O.) sanjavieri, Tejerina \& Paggi 2009). The second group contains specimens with long dorsal setae 1 and 3 and very long medium precorneal setae (Table 5). In between this large group, two subgroups can also be distinguished, the GUAYo4 samples, with spines in the sternites II and III longer than $5 \mu \mathrm{m}$, which correspond to $C$. (O.) rieradevallae sp. $\mathrm{n}$. described in this paper, and the others ( $C$.
(O.) sp. Santa) that do not have such spines (or only very small ones) and according to the molecular analysis belong to undescribed species. Also, the distance between the AS1 and AS2 in these two subgroups is different (Fig 5g, h). The respiratory organ (RO) is of similar length among all the pupae studied except for the sole pupal exuviae found in the Aguarico stream (AGU14 in Table 8; Fig 5c) which is shorter and without final notch, while in all the other pupae, the RO has a distinctive notch in the terminal part that is serrated (Figs $3 a$ and $5 a-b$, d). The RO of $C$. (O.) almeidai and $C$. (O.) sanjavieri do not have this notch. The length of the RO is similar in the pupae that we have examined and similar to the length of the other two species described until now. The mean number of hooklets in the tergites is lower than those found in the two other described species (Table 8) but this number is very variable. 
The pupal characteristics facilitated the description of a preliminary key of the morphotypes known at present, which most likely belong to different species.

\section{Preliminary key of the pupae of Cricotopus (Oliveiriella)}

1. All precorneal and dorsocentral setae short (max $120 \mu \mathrm{m}$ ) (Fig 5e)

- $\quad$ One precorneal setae much longer (over $180 \mu \mathrm{m}$ ) than the other two (Fig $5 f$ ). Dorsocentral setae 1 and 3 longer (over $140 \mu \mathrm{m}$ ) compared with 2 and 4 (Fig 3b) ............... 4

2. Respiratory organ with a conspicuous notch (Fig 5a). Less than $20 \mathrm{HR}$ spines in abdominal segment III C. (O.) sp. Chinchiná

- $\quad$ Respiratory organ without a notch. More than $20 \mathrm{HR}$ spines in abdominal segment III ....

3. RO simple apex, blunt. Length: $181 \mu \mathrm{m}$ (136-242) C. (O.) almeidai (Oliveira)

RO serrated at tip: Length: $246 \mu \mathrm{m}$ (220-280)

C. (O.) sanjavieri Tejerina \& Paggi

4. Without spines, or with only very small ones, in the abdominal sternites II and III. RO with a distal notch (Fig 5d) C. (O.) sp. Santa With apparent spines (between 6 and $12 \mu \mathrm{m}$ ) in the abdominal sternites II and III (Fig 3d, e). RO with or without a distal notch

5. Large species, RO over $3.5 \mathrm{~mm}$ and with a notch in the tip (Fig 5b) C. (O.) rieradevallae $\mathrm{sp} . \mathrm{n}$. Smaller species, RO below $3 \mathrm{~mm}$ and without a notch (Fig 5c) C. (O.) sp. Aguarico

\section{Discussion}

In this paper, we describe a new species of Cricotopus (Oliveiriella) from all their instars and we include the molecular characteristics. The use of molecular analysis confirms the statement of Andersen et al (2013), based on morphological characteristics, that Oliveiriella must be included in the genus Cricotopus as a subgenus. Our molecular data, thus, support the inclusion of Oliveiriella as a subgenus of Cricotopus.

Cricotopus (Oliveiriella) rieradevallae sp. $\mathrm{n}$. may be distinguished from the other described species of these subgenera in all three instars. The adult has a different pattern of spots on the wing and different color patterns in the legs and abdomen, as well as a different number of bristles in the squama and clypeus. The pupae may be distinguished by the size and form of the respiratory organ (RO) and the length of the medium setae of precorneals and the length of dorsocentral setae 1 and 3 , and the presence of spines in the sternites II and III. Larvae are larger than those of the other species.
In the pupae examined in the sites studied (see Tables 1 and 8 ), we found very different combinations of the size and form of the RO, in the size of the precorneal and dorsocentral setae, and in the presence or not of spines of sternites II and III. This suggests the possible presence of at least four new species, which is supported by the molecular analysis. All the Oliveiriella converge among themselves before converging with other Cricotopus. The already known species $C$. (O.) almeidai (from Argentina) is clearly distinguished from the other species and is more similar to our material from Peru and Colombia than those of Ecuador.

There are four distinct populations of the Andean central area: Ecuador (NAO2 and GUAYO4), Peru (MOO8), and Colombia (VR-6). Interestingly, the two late populations seem to be identical despite the fact that they are more distant than the NA and GUAY materials. Note that all the material was collected at high altitude.

In this paper, we enlarged considerably the distribution of the subgenus Cricotopus (Oliveiriella) to the north and to the high-altitude rivers. We have found larvae and pupae of $C$. (Oliveiriella) at high-altitude Andean streams between 2457 and $3845 \mathrm{~m}$ a.s.l., in eight of the 186 sites we studied. Although we found larvae in the Saltana river throughout the year and the adults flying most of the year at this site, the abundance was never as high as other Cricotopus. The two species known to be present, i.e., $C$. (O.) sanjavieri and $C$. (O.) almeidai, were found in Argentina and Brazil (Paggi \& Donato 2007, Tejerina \& Paggi 2009, Tejerina \& Malizia 2012, Wiedenbrug \& Fittkau 1997). Larvae and pupae of an unknown species have been found in North America (Krestian et al 2009) which most likely means that the subgenus has a wide distribution in South and Central America. Although we have described only one species in this paper (C. (O.) rieradevallae), the differences found in the pupae and pupal exuviae collected in other high-altitude Andean streams indicate that many species are likely to be present, which is corroborated by the molecular analysis that differentiates $C$. (O.) almeidai of the Andean species while up to three species may be distinguished from the material collected in the central Andes.

Acknowledgments The authors are very indebted to our Latin American colleagues that made possible the collection of chironomid larvae in Colombia (Lucimar Gomes, Universidad de Caldas), Ecuador (Andrea Encalada, Maja and Natalia García, Universidad San Francisco de Quito), and Peru (Clorinda Vergara and Javier Huanca, Universidad Nacional Agraria de La Molina). Many other people helped in the field collections, and we thank Carolina Arroyo, Fernanda González, Karla Jiménez, and Manuel Andía for their support. Larvae and pupae of Cricotopus (O.) almeidai were provided by M. Donato and A. Siri and larvae of $C$. (O.) sanjavieri by E. Tejerina. We thank all of them for the material loaned. Núria Sánchez Millaruelo and Pau Fortuño prepared most of the slides and figures respectively. This paper is a scientific 
contribution no. 995 of the Instituto de Limnologia "Raúl A. Ringuelet" de la Plata.

Electronic supplementary material The online version of this article (doi:10.1007/s13744-017-0548-5) contains supplementary material, which is available to authorized users.

\section{References}

Acosta R, Rios-Touma B, Rieradevall M, Prat N (2009) Propuesta de un protocolo de evaluación de la calidad ecológica de rios Andinos (C.E.R.A) y su aplicación en dos cuencas en Ecuador y Perú. Limnetica 28:35-64

Acosta R, Prat N (2010) Chironomidae assemblages in high altitude streams of the Andean region of Peru. Fundam Appl Limnol 177:57-79

Andersen T, Saether OA, Cranston PS, Epler JH (2013) The larvae of Orthocladiinae (Diptera: Chironomidae) of the Holarctic Region. Keys and diagnoses. In: Andersen T, Cranston PS, Epler JH (eds) The larvae of Chironomidae (Diptera) of the Holarctic Region. Keys and diagnoses. Insect Syst Evol Suppl.66 Lund Sweden, pp 189-386

Cranston, P. S. (2000) The electronic guide of Chironomidae of Australia. http://apes.skullisland.info/node/3 Accessed 2000

Cranston PS, Hardy NB, Morse GE, Pusledik L, McCluen SR (2010) When molecules and morphology concur: the "Gondwanan" midges (Diptera: Chironomidae). Syst Entomol 35:635-648

Drummond AJ, Ashton B, Cheung M, Heled J, Kearse M, Moir R (2009) Stones-Havas S, Thierer T, Wilson A Geneious v.4.6.5. Created by Biomatters

Epler J (2001) Identification manual for the larval Chironomidae (Diptera) of North and South Carolina. A guide to the taxonomy of the midges of southeastern United States, including Florida. North Carolina Department of Environment and Natural Resources, Raleigh, NC and St. Johns River Water Management District, Plalatka, FL., Special Publication SJ2011-SP13, 526p

Krestian BJ, Kosnicki E, Spindler PH, Stringer S, Epler JH (2009) First neartic records of Oliveiriella Wiedenbrug and Fittkau, with new distributional records for two other new world species of Orthocladiinae (Diptera: Chironomidae). Entomol News 120:349-362

Krosch MN, Baker AM, Cranston PS (2011) Systematics and biogeography of the Gondwanan Orthocladiinae (Diptera: Chironomidae). Mol Phylogenet Evol 59:458-468

Kumar S, Stecher G, Tamura K (2016) MEGA7: Molecular Evolutionary Genetics Analysis version 7.0 for bigger datasets. Mol Biol Evol 33: 1870-1874

Montagna M, Mereghetti V, Lencioni V, Rossaro B (2016) Integrated taxonomy and DNA barcoding of alpine midges (Diptera: Chironomidae). PLoS One 11(3):e0149673. doi:10.1371/journal.pone. 0149673

Oliveira SJ (1946) Sobre um novo Orthocladiinae neotrópico (Diptera, Chironomidae). In: Livro de homenagem a R. F.Almeida, Imprensa Oficial do Estado de São Paulo, São Paulo, pp 279-282

Paggi AC (2009) Chironomidae. In: Domínguez E, Fernández H (eds) Macroinvertebrados bentónicos sudamericanos. Sistemática y biología. Fundación Miguel Lillo, Tucumán, pp 383-409

Paggi AC, Donato M (2007) Redescription of the female of Oliveiriella almeidai (Chironomidae: Orthocladiinae). Rev Soc Entomol Argent 66: 155-158
Prat N, Acosta R, Villamarín C, Rieradevall M (2012) Guía para el reconocimiento de las larvas de Chironomidae (Diptera) de los ríos Altoandinos de Ecuador y Perú. Clave para la determinación de los principales morfotipos larvarios. Grupo de Investigación F.E.M. (Freshwater Ecology and Management), Departament d'Ecologia, Universitat de Barcelona, http://www.ub.edu/riosandes/index.php/ guiachiros.html

Prat N, Ribera C, Rieradevall M, Villamarin C, Acosta R (2013) Distribution, abundance and molecular analysis of Barbadocladius Cranston \& Krosch (Diptera, Chironomidae) in tropical, high altitude Andean streams and rivers. Neotrop Entomol 42:607-617

Prat N, González-Trujillo JD, Ospina-Torres R (2014) Clave para la determinación de exuvias pupales de los quironómidos (Diptera: Chironomidae) de ríos altoandinos tropicales. Rev Biol Trop 62: 1385-1406

Prat N, Rios-Touma B, Encalada A (in prep) Composition, life-history, population dynamics and secondary production of the Chironomidae from a tropical high altitude stream (river Saltana, Ecuador)

Ríos-Touma B, Encalada A, Prat N (2011) Macroinvertebrate assemblages of an Andean high-altitude tropical stream: the importance of season and flow. Internat Rev Hydrobiol 96:667-685

Ríos-Touma BP, Encalada AC, Bonada N, Rieradevall M, González F, Prat $\mathrm{N}$ (2012) The role of flow shaping the functional and structural invertebrate diversity at a high altitude tropical stream. 97th Annual Meeting of the Ecological Society of America PS: 2-57

Roback SS, Coffman WP (1983) Results of the Catherwood BolivianPeruvian Altiplano expedition. Part II. Aquatic Diptera including montane Diamesinae and Orthocladiinae (Chironomidae) from Venezuela. Proc Acad Nat Sci Philadelphia 135:9-79

Saether OA (1980) Glossary of chironomid morphology terminology (Diptera: Chironomidae). Ent Scand Suppl 14:1-51

Silvestro D, Michalak I (2012) RaxmIGUI: a graphical front-end for RAxML. Org Divers Evol 12:335-337

Stamatakis A (2006) RAxML-VI-HPC: maximum likelihood-based phylogenetic analyses with thousands of taxa and mixed models. Bioinformatics 22:2688-2690

Tamura K, Peterson D, Peterson N, Stecher G, Nei M, Kumar S (2011) MEGA5: molecular evolutionary genetics analysis using maximum likelihood, evolutionary distance, and maximum parsimony methods. Mol Biol Evol 28:2731-2739

Tejerina EG, Paggi AC (2009) A new Neotropical species of Oliveiriella Wiedenburg \& Fittkau (Diptera, Chironomidae) from Argentina, with description of all life stages. Aquat Insect 31:91-98

Tejerina EG, Malizia A (2012) Chironomidae (Diptera) larvae assemblages differ along an altitudinal gradient and temporal periods in a subtropical montane stream in Northwest Argentina. Hydrobiologia 686:4154

Villamarín C, Rieradevall M, Paul MJ, Barbour MT, Prat N (2013) A tool to assess the ecological condition of tropical high Andean streams in Ecuador and Peru: the IMEERA index. Ecol Indic 29:79-92

Villamarín C, Prat N, Rieradevall M (2014) Caracterización física, química e hidromorfológica de los ríos altoandinos tropicales de Ecuador y Perú. Lat Am J Aquat Res 42:1072-1086

Wiedenbrug S, Fittkau EJ (1997) Oliveiriella almeidai (Oliveira, 1946), gen nov., comb. nov., from South America with description of the pupae. Spixiana 20:167-172 